\title{
Biopsychosocial Determinants of Long-term Contraceptive Use in Women of Reproductive Age in Surakarta, Central Java
}

\author{
Ratna Arifiana1), Uki Retno Budihastuti2), Isna Qadrijati3) \\ ${ }^{1)}$ Masters Program in Public Health, Universitas Sebelas Maret \\ 2)Department of Obstetrics and Gynecology, Dr. Moewardi Hospital, Surakarta \\ 3)Faculty of Medicine, Universitas Sebelas Maret
}

\begin{abstract}
Background: Family planning allows people to attain their desired number of children and determine the spacing of pregnancy. Long-term contraceptive methods are more effective, safe, with fewer contraindications than others contraceptive method. This study aimed to investigate the biopsychosocial determinants of long-term contraceptive use in women of reproductive age in Surakarta, Central Java, using theory of planned behavior.

Subjects and Method: This was an analytic observational study with a case-control design. The study was conducted in Surakarta, from January to February 2018. A sample of 210 women of reproductive age was selected for this study by fixed disease sampling. The dependent variable was long-term contraceptive use. The independent variables were age, parity, education, employment status, knowledge, attitude, subjective norm, perceived behavior control, husband support, family income, and health counseling. The data was collected by questionnaire and analyzed by path analysis.

Results: Long-term contraceptive use increased with positive attitude $(b=3.49 ; 95 \% \mathrm{CI}=1.88$ to 5.11; $\mathrm{p}<0.001)$, supportive subjective norm $(\mathrm{b}=2.91 ; 95 \% \mathrm{CI}=1.10$ to $4.73 ; \mathrm{p}=0.002)$, strong perceived behavior control $(\mathrm{b}=3.09 ; 95 \% \mathrm{CI}=1.29$ to $4.88 ; \mathrm{p}=0.001)$, and strong husband support $(\mathrm{b}=2.68 ; 95 \% \mathrm{CI}=1.04$ to $4.33 ; \mathrm{p}=0.001)$. Long-term contraceptive use was indirectly affected by age, knowledge, health conselling, and education level.

Conclusion: Long-term contraceptive use increases with positive attitude, supportive subjective norm, strong perceived behavior control, and strong husband support.
\end{abstract}

Keywords: long-term contraceptive, theory of planned behavior, path analysis

\section{Correspondence:}

Ratna Arifiana, Masters Program in Public Health, Universitas Sebelas Maret, Jl. Ir. Sutami 36 A, Surakarta 57126, Central Java. Email: arifianaratna1301@gmail.com.

\section{BACKGROUND}

The degree of public health can be measured through several indicators, one of them is by looking at the maternal mortality. According to the 2015 Intercensal Population Survey (SUPAS), In Indonesia, there were 305 maternal deaths per 100,000 live births, which is still quite high compared to the target of SDG's stating that by 2030, MMR can reach below 70 per 100,000 live births. The risk factors for maternal mortality include $4 \mathrm{~T}$, namely Too young when the birth delivery is done (less than 20 years of age), Too often to give birth, Too near between one birth and another one, and Too old when the birth delivery takes place (age above 35 years). One effort to reduce maternal mortality rate is by using Family Planning program (Kemenkes RI, 2015). Long-term contraceptive methods are considered to be more effective, safer, longer-term, and have less contraindications than non-long term contraceptive methods (MKJP), but the use of long-term contraceptive methods is 
Journal of Health Promotion and Behavior (2018), 3(1): 37-47

https://doi.org/10.26911/thejhpb.2018.03.01.04

much lower than non-long-term contraceptive methods (Shoupe, 2016).

The use of permanent and long-term contraceptives in Ethiopia accounts for only $5 \%$ of all types of contraceptives, with the highest use of contraceptives reching 70\% (Mekonnen et al., 2017). The lack of use of MKJP is also experienced in South Africa, it is estimated that the use of MOW method is about $10 \%$, and the use of IUD method is less than 1\% (Credé et al., 2012). The use of MKJP in Uganda is still low, this can be demonstrated by the number of users that is only $13 \%$ of all women, the IUD method is the lowest method of users which is $0.4 \%$, while the implant has $1.9 \%$ of users (Anguzu et al., 2014).

The use of MKJP in new KB participants is still low, including implant (9.63\%), IUD (6.81\%), and MOW (1.64\%), whereas non-MKJP use is injection (49.93\%), pill (26.36\%), and condoms (5.47\%) (Ministry of Health, 2015). The coverage of new KB participants according to data from the Central Java Health Office from 2014 was $13.9 \%$ at first berfore it decreased in 2015 to $12.5 \%$.

The use of MKJP is relatively lower compared to non-MKJP contraceptive method, in 2014, FP participants using MKJP were 26.5\% while non-MKJP were $73.5 \%$. The use of tools and drugs of shortterm contraceptive methods continued to increase from $46.5 \%$ to $47.3 \%$, while MKJP tended to decrease from $10.9 \%$ to $10.6 \%$ (Ministry of Health, 2015). In $2015 \mathrm{~KB}$ participants using MKJP were 27.2\% while non-MKJP were $72.7 \%$. The number of new family planning participants in 2014 in Surakarta was the lowest with the number of EUS of 70,408 that was followed the new $\mathrm{KB}$ for about 7,349 (10\%) (Central Java Provincial Health Office, 2014). The subdistrict with the highest number of MKJP (IUD, implant, MOW) users in Surakarta
City is Jebres Sub-district with the number of MKJP users per March 2017 of 4,350 people (DPPKB, 2017).

The use of contraceptive types by WUS may be affected by some factors such as age, parity, education, occupation, social support, self efficacy, the role of health personnel, and income. Some of the factors in long-term use of contraception include age, parity, and education. Mothers aged over 35 years prefer to use long-term family planning, and mothers with 4-5 children mostly prefer to use long-term contraceptives, long-term use of contraceptives is mostly used by more educated mothers, some mothers still have the wrong belief and fear to use long-term contraception, they argue that using Implants and IUDs will cause cancer (Tibaijuka et al., 2017).

There are some fctors that affect the use of contraception, one of them is social support, especially from the husband, couples should support each other including supporting the use of contraceptives (Gebremariam, 2014). The occupational factors will also affect the use of contraception in mothers, this is supported by a study stating that occupations have a significant relationship to long-term use of contraception, 28 out of 29 working women used long-term contraceptives (Sahilemichaelet al, 2015). Provision of counseling and IEC by health personnel has not been effective, it can be seen from the mother's knowledge about family planning and contraception which is still high (98\% of EFA) but the participant of $\mathrm{KB}$ were only $57,9 \%$ (BKKBN, 2016).

\section{SUBJECTS AND METHOD}

\section{Study Design}

The study design used was observational analytics with a case-control approach. The study was conducted in Surakarta from January to February 2018. 


\section{Population and Sample}

The target population in this study was all WUS using MKJP and Non-MKJP, while the source population was WUS using MKJP and Non-MKJP in Jebres Subdistrict, Surakarta. The sample size in this study was 210 subjects selected through fixed desease sampling consisting of 70 users of MKJP (case) and 140 non-MKJP (control).

\section{Study Variables}

The dependent variable is the use of longterm contraception, while the independent variables include age, parity, education, occupation, husband support, counseling, income, knowledge, attitude, subjective norm, and perception of behavioral control.

4. Operational Definition of Variables The use of long-term contraceptives was defined as the use of contraceptive methods used by women of infertile age to regulate or limit the number of children they wish to have using both long-term contraceptive method and non long-term contraceptive method. The data were collected by questionnaire. The measurement scale was categorical, coded o for did not use and 1 for use long term contraceptive method.

Maternal age was defined as the period of life of the mother is calculated from birth until the data is taken. The data were collected by questionnaire. The measurement scale was continuous, but for the purpose of data analysis, it was transformed into dichotomous coded o for $<35$ years old and 1 for $\geq 35$ years old.

Parity was defined as the number of live births performed by the mother. The data were collected by questionnaire. The measurement scale was continuous, but for the purpose of data analysis, it was transformed into dichotomous coded o for primigravida and 1 for multigravida.

Education level was defined as the highest formal education level achieved by mothers starting from elementary, junior high, senior high, and college level. The data were collected by questionnaire. The measurement scale was categorical, coded o for $<$ Senior high school and 1 for $\geq$ Senior high school.

Occupation was defined an activity undertaken by the mother to earn a living or income. The data were collected by questionnaire. The measurement scale was continuous.

Husbands' support was defined as the support or assistance of husbands received by mothers in the use of contraceptives either through emotional support, award support, instrumental support, and informational support regarding the use of contraceptive methods. The data were collected by questionnaire. The measurement scale was continuous.

Conselling was defined as the provision of information on Family Planning by health personnel on prospective family planning acceptors on long term contraception method. The data were collected by questionnaire. The measurement scale was continuous, but for the purpose of data analysis, it was transformed into dichotomous coded o for no and 1 for yes.

Income was defined as the economic ability that a person obtains to meet his or her life needs, calculated on average per six months. The data were collected by questionnaire. The measurement scale was continuous, but for the purpose of data analysis, it was transformed into dichotomous coded o for low income and 1 for high income.

Knowledge was defined as all that the mother knows about contraceptive methods including definitions, effectiveness, indications, contraindications, side effects, and the procedure. The data were collected by questionnaire. The measurement scale was 
Journal of Health Promotion and Behavior (2018), 3(1): 37-47

https://doi.org/10.26911/thejhpb.2018.03.01.04

continuous, but for the purpose of data analysis, it was transformed into dichotomous coded o for poor knowledge and 1 for good knowledge.

Attitude was defined as a WUS response in the form of a positive or negative assessment to persuade the mother to use long-term contraception. The data were collected by questionnaire. The measurement scale was continuous, but for the purpose of data analysis, it was transformed into dichotomous coded o for negative attitude and 1 for positive attitude.

Subjective norms was defined as beliefs support felt by mother from the social, family, and friend who have an impact on maternal decisions on using long-term contraceptive. The data were collected by questionnaire. The measurement scale was continuous, but for the purpose of data analysis, it was trans-

Table 1. The results of reliability test

\begin{tabular}{clc}
\hline No & \multicolumn{1}{c}{ Variables } & Cronbach's Alpha \\
\hline 1. & Husband support & 0.825 \\
2. & Knowledge & 0.878 \\
3. & Attitude & 0.896 \\
4. & Subjective norm & 0.919 \\
5. & Perceived behavior control & 0.833 \\
\hline
\end{tabular}

\section{Data Analysis}

Data analysis of the result used path analysis with Stata 13 program to know the influence of independent variable (age, parity, education, employment, husband's support, counseling, income, knowledge, attitude, subjective norms, and perceived behavior control) to dependent variable (long-term contraceptive use) and to know the magnitude influence on that variable.

\section{Research Ethics}

The research ethical clearance was granted from the Research Ethics Committee at Dr. Moewardi Hospital, Surakarta, Central Java, Indonesia. Research ethics included issues such as informed consent, anonymity, confidentiality, and ethical clearance. formed into dichotomous coded $\mathrm{o}$ for negative subjective norm and 1 for positive subjective norm.

Perceived behavioral control was defined as beliefs of the mothers in using long-term contraceptives. The data were collected by questionnaire. The measurement scale was continuous, but for the purpose of data analysis, it was transformed into dichotomous coded $\mathrm{o}$ for negative perceived behavior control and 1 for positive perceived behavior control.

\section{Study instrument}

Table 1 showed the results of reliability test of the instruments collecting data on husband support, maternal knowledge, attitude, subjective norm, and perceived behavior control. The Alpha Cronbach of each of these variables exceeds $\alpha \geq 0.70$, confirming that the minimum requirement of internal consistency was met.

\section{Univariate Analysis}

Table 2 shows that as many as 124 mothers (59\%) were aged $\geq 35$ years. As many as 157 mothers (74.8\%) were multiparous. As many as 140 mothers (66.7\%) used nonlong term contraceptive method.

As many as 152 mothers (72.4\%) attained $\geq$ senior high school. As many as 143 mothers were working outside the house (68.1\%). As many as 133 mothers (63.3\%) received conselling.

As many as 136 mothers (64.8\%) had high family income. As many as 109 mothers $(51.9 \%)$ received strong husband support. As many as 129 mothers (61.4\%) 
had poor knowledge about long term contraceptive method. As many as 118 mothers (56.2\%) had negative attitude, 111
(52.9\%) had negative subjective norm, and 109 mothers (51.9\%) positive perceived behavior control.

Table 2. Univariate Analysis of Variables

\begin{tabular}{|c|c|c|}
\hline $\begin{array}{r}\text { Variable } \\
\end{array}$ & $\mathbf{n}$ & (\%) \\
\hline \multicolumn{3}{|l|}{ Contraception } \\
\hline Non-long term contraceptive use & 140 & 66.7 \\
\hline Long term contraceptive use & 70 & $33 \cdot 3$ \\
\hline \multicolumn{3}{|l|}{ Age } \\
\hline$<35$ years old & 86 & 41 \\
\hline$\geq 35$ years old & 124 & 59 \\
\hline \multicolumn{3}{|l|}{ Parity } \\
\hline Primigravida & 53 & 25.2 \\
\hline Multigravida & 157 & 74.8 \\
\hline \multicolumn{3}{|l|}{ Education } \\
\hline Low & 58 & 27.6 \\
\hline High & 152 & 72.4 \\
\hline \multicolumn{3}{|l|}{ Occupation } \\
\hline Housewife & 67 & 31.9 \\
\hline Working outside & 143 & 68.1 \\
\hline \multicolumn{3}{|l|}{ Counseling } \\
\hline No & 77 & 36.7 \\
\hline Yes & 133 & 63.3 \\
\hline \multicolumn{3}{|l|}{ Income } \\
\hline Low & 74 & 35.2 \\
\hline High & 136 & 64.8 \\
\hline \multicolumn{3}{|l|}{ Family support } \\
\hline Weak & 101 & 48.1 \\
\hline Strong & 109 & 51.9 \\
\hline \multicolumn{3}{|l|}{ Knowledge } \\
\hline Poor & 129 & 61.4 \\
\hline Good & 81 & 38.6 \\
\hline \multicolumn{3}{|l|}{ Attitude } \\
\hline Negative & 118 & 56.2 \\
\hline Positive & 92 & 43.8 \\
\hline \multicolumn{3}{|l|}{ Subjective Norms } \\
\hline Negative & 111 & 52.9 \\
\hline Positive & 99 & 47.1 \\
\hline \multicolumn{3}{|l|}{ Perceived Behavior Control } \\
\hline Negative & 101 & 48.1 \\
\hline Positive & 109 & 51.9 \\
\hline
\end{tabular}

\section{Bivariate Analysis}

Bivariate analysis was used to analyze the relationship of independent variables (age, parity, education, employment, husband's support, counseling, income, knowledge, attitude, subjective norms, and perceived behavior control) with dependent variable (long-term contraceptive use).

Table 3 showed that there was a significant effect of subjective norms, perceived behavior control, attitude, husband's support, knowledge, counseling, education, and age on long-term contraceptive use. 
Journal of Health Promotion and Behavior (2018), 3(1): 37-47

https://doi.org/10.26911/thejhpb.2018.03.01.04

Table 3. Bivariate analysis effect of independent variables with long-term contraceptive use

\begin{tabular}{|c|c|c|c|c|c|c|c|c|c|}
\hline \multirow[b]{2}{*}{ Independent Variables } & \multicolumn{2}{|c|}{ Non-LTCM } & \multicolumn{2}{|c|}{ LTCM } & \multicolumn{2}{|c|}{ Total } & \multirow[b]{2}{*}{$\mathbf{O R}$} & \multirow[b]{2}{*}{$95 \% \mathrm{CI}$} & \multirow[b]{2}{*}{$\mathbf{p}$} \\
\hline & $\begin{array}{c}n= \\
140\end{array}$ & $\%$ & $\begin{array}{l}n= \\
70\end{array}$ & $\%$ & $\begin{array}{c}n= \\
210\end{array}$ & $\%$ & & & \\
\hline \multicolumn{10}{|l|}{ Age } \\
\hline$<35$ years old & 57 & 66.3 & 29 & $33 \cdot 7$ & 86 & 100 & 0.97 & 0.54 to & 0.921 \\
\hline$\geq 35$ years old & 83 & 66.9 & 41 & 33.1 & 124 & 100 & & 1.74 & \\
\hline \multicolumn{10}{|l|}{ Parity } \\
\hline Primigravida & 41 & 77.4 & 12 & 22.6 & 53 & 100 & 2.00 & 0.97 to & 0.056 \\
\hline Multigravida & 99 & 63.1 & 58 & 36.9 & 157 & 100 & & 4.11 & \\
\hline \multicolumn{10}{|l|}{ Education } \\
\hline Low & 45 & 77.6 & 13 & 22.4 & 58 & 100 & 2.08 & 1.03 to & 0.038 \\
\hline High & 95 & 62.5 & 57 & 37.5 & 152 & 100 & & 4.179 & \\
\hline \multicolumn{10}{|l|}{ Employment } \\
\hline Working at home & 53 & 79.1 & 14 & 20.9 & 67 & 100 & 2.44 & 1.24 to & 0.009 \\
\hline Working outside the house & 87 & 60.8 & 56 & 39.2 & 143 & 100 & & 4.80 & \\
\hline \multicolumn{10}{|l|}{ Husband's Support } \\
\hline Weak & 95 & 94.1 & 6 & $5 \cdot 9$ & 101 & 100 & 22.52 & 9.07 to & $<0.001$ \\
\hline Strong & 45 & 41.3 & 64 & 58.7 & 109 & 100 & & 55.88 & \\
\hline \multicolumn{10}{|l|}{ Counseling } \\
\hline No & 73 & 94.8 & 66 & 5.2 & 77 & 100 & 17.98 & 6.21 to & $<0.001$ \\
\hline Yes & 67 & 50.4 & & 49.6 & 133 & 100 & & 52.01 & \\
\hline \multicolumn{10}{|l|}{ Income } \\
\hline Low & 45 & 60.8 & 29 & 39.2 & 74 & 100 & 0.67 & 0.37 to & 0.184 \\
\hline High & 95 & 69.9 & 41 & 30.1 & 136 & 100 & & 1.21 & \\
\hline \multicolumn{10}{|l|}{ Knowledge } \\
\hline Poor & 124 & 96.1 & 5 & 3.9 & 129 & 100 & 100.75 & $35 \cdot 32$ to & $<0.001$ \\
\hline Good & 16 & 19.8 & 65 & 80.2 & 81 & 100 & & 287.35 & \\
\hline \multicolumn{10}{|l|}{ Attitude } \\
\hline Negative & 115 & $97 \cdot 5$ & 3 & 2.5 & 118 & 100 & 102.73 & 29.88 to & $<0.001$ \\
\hline Positive & 25 & 27.2 & 67 & 72.8 & 92 & 100 & & 353.19 & \\
\hline \multicolumn{10}{|l|}{ Subjective Norm } \\
\hline Negative & 106 & $95 \cdot 5$ & 5 & 4.5 & 111 & 100 & 40.53 & 15.09 to & $<0.001$ \\
\hline Positive & 34 & $34 \cdot 3$ & 65 & $65 \cdot 7$ & 99 & 100 & & 108.88 & \\
\hline \multicolumn{10}{|l|}{ PBC } \\
\hline Negative & 98 & 97.0 & 3 & 3.0 & 101 & 100 & 52.11 & 15.51 to & $<0.001$ \\
\hline Positive & 42 & 38.5 & 67 & 61.5 & 109 & 100 & & 175.07 & \\
\hline
\end{tabular}

\section{Path Analysis Results}

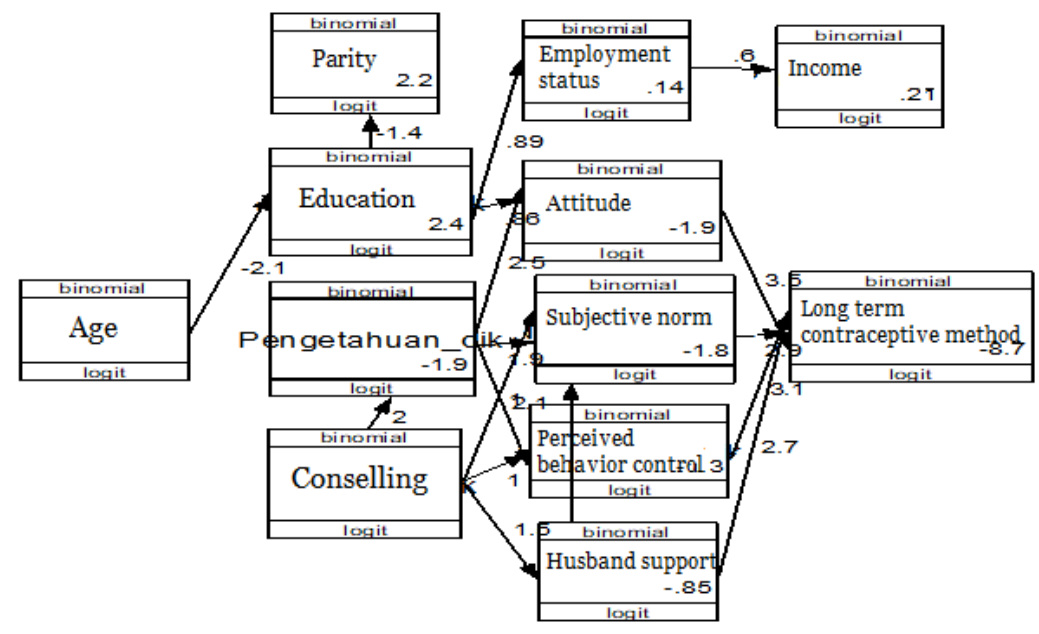

Figure 1. Structural model with estimation 
Table 4. Path Analysis Results

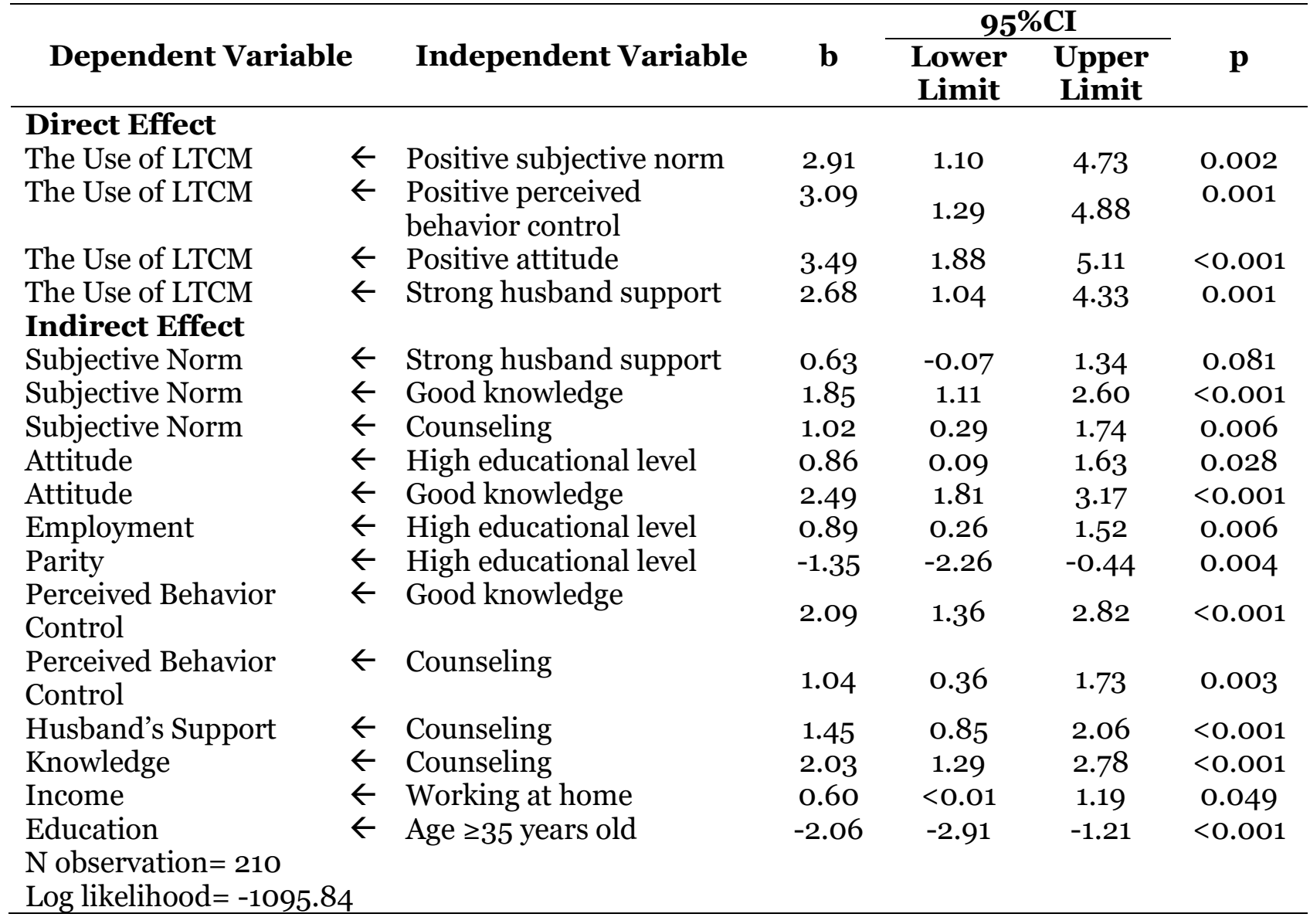

Long-term contraceptive use was affected by positive subjective norm $(\mathrm{b}=$ 2.91; CI $95 \%=1.10$ to 4.73 ; $\mathrm{p}=0.002)$, positive perceived behavior control $(\mathrm{b}=3.09$; $\mathrm{CI}$ $95 \%=1.29$ to $4.88 ; \mathrm{p}=0.001$ ), positive attitudes $(b=3.49$; CI $95 \%=1.88$ to 5.11 ; $\mathrm{p}<0.001)$, and strong husbands support $(\mathrm{b}=$ 2.68; CI 95\%= 1.04 to $4.33 ; \mathrm{p}=0.001$ ).

Subjective norm was affected by strong husband support $(b=0.63$; CI 95\%= -0.07 to $1.34 ; \mathrm{p}=0.081)$, knowledge $(\mathrm{b}=$ 1.02; CI $95 \%=1.11$ to $2.60 ; \mathrm{p}<0.001$ ), and counseling $(b=1.02$; CI $95 \%=0.29$ to 1.74 ; $\mathrm{p}=0.006$ ).

Attitudes were affected by educational level $(b=0.86$; CI $95 \%=0.09$ to $1.63 ; \mathrm{p}=$ 0.028) and knowledge $(\mathrm{b}=2.49$; CI $95 \%=$ 1.81 to 3.17 ; $\mathrm{p}<0.001$ ).
Employment $(\mathrm{b}=0.89$; CI 95\%=0.26 to $1.52 ; \mathrm{p}=0.006)$ and parity $(\mathrm{b}=-1.35 ; \mathrm{CI}$ $95 \%=-2.26$ to $-0.44 ; \mathrm{p}=0.004)$ was affected by educational level.

Perceived behavior control was affected by knowledge $(b=2.09$; CI $95 \%=1.36$ to 2.82; $\mathrm{p}<0.001)$ and counseling $(\mathrm{b}=1.04$; $\mathrm{CI}$ $95 \%=0.36$ up to $1.73 ; \mathrm{p}=0.003)$.

Husband's support $(\mathrm{b}=1.45$; CI $95 \%=$ 0.85 to $2.06 ; \mathrm{p}<0.001)$ and knowledge ( $b=2.03$; CI $95 \%=1.29$ to 2.78 ; $\mathrm{p}<0.001)$ affected by counseling.

Income $(b=0.60 ; \mathrm{CI} 95 \%<0.01$ to 1.19; $\mathrm{p}=0.049$ ) was affected by employment. Education $(b=-2.06$; CI 95\%= -2.91 to $-1.21 ; \mathrm{p}<0.001$ ) was affected by age. 


\section{DISCUSSIONS \\ 1. The effect of subjective norm on the use of LTCM}

The result of analysis showed that subjective norm has positive effect on the use of long-term contraceptive. The result of this study was in line with a study by Joeliatin et al, (2016), which stated that mothers with positive subjective norm would improve the positive attitudes, therefore, they would use LTCM. The subjective norms about IUD contraceptives were less positive among mothers, information gained through people would affect the maternal behavior, if the mothers heard misunderstanding of information about the IUD, then the mother would be affected by the thought, therefore, it would decrease their desire to use IUD (Garret et al, 2015).

\section{The effect of perceived behavior control on the use of LTCM}

The result of analysis showed that perceived behavior control has positive effect on the use of long-term contraceptive. The result of this study was in line with a study by Joeliatin (2016) which stated that mothers with positive perceived behavior control would increase the use of LTCM. Mothers who have confidence would be more assured in doing a behavior.

\section{The effect of attitudes on the use of LTCM}

The result of analysis showed that attitudes affected the use of long-term contraceptive. The result of this study was in line with a study by Meskele and Mekonnen (2014) which stated that mothers who have positive attitudes would improve the use of LTCM by 2.5 times higher. Maternal belief that LTCM was more effective would foster maternal positive attitudes toward the LTCM (Tibaijuka et al, 2017).

A positive attitude can be gained through good knowledge of LTCM so that the mothers were not afraid to use LTCM (Haile et al., 2016).

\section{The effect of husband support on the use of LTCM}

The result of analysis showed that husband support the use of long-term contraceptive. The result of this study was in line with a study by Alemayehu et al, (2015) which stated that husbands' support can affect mothers in making decisions to use longterm contraception. Licensing and consent of the spouse would increase the use of LTCM (Anguzu et al, 2014).

\section{The effect of knowledge on the use of LTCM}

The result of this study showed that knowledge through subjective norms has an effect on the use of long-term contraceptive. The result of this study was in line with a study by Bultoet et al, (2014) which stated that mothers with good knowledge of LTCM would use LTCM, the benefits of using LTCM were able to control birth spacing and limit the number of children effectively.

Information obtained by mothers either through social media, as well as health personnels will lead to new knowledge that can transferred the information about the use of long-term contraceptive (Takeleet al, 2012). Mothers with good knowledge can estimate the risks and benefits of LTCM (Getinetet al, 2014).

\section{The effect of counseling on the use of LTCM}

The result of this study showed that counseling through subjective norms has an effect on the use of long-term contraceptive. The result of this study was in line with a study by Zenebe et al, (2017) which stated that mothers who have received information or counseling about LTCM were 8.85 times more likely to use LTCM. Maternal knowledge would increase if it has obtained information or counseling in 
order to change the perception and a more positive attitude towards LTCM. The information about LTCM mostly obtained through health personnels from public health facilities (Haile et al, 2016).

\section{The effect of education on the use of LTCM}

The result of this study showed that education through attitudes has an effect on the use of long-term contraceptive. The result of this study was in line with a study by Zenebe et al, (2017) which stated that highly-educated mothers would increase the use of long-term contraceptive. Mothers with high educational level would improve the chance to gain the access to information and good knowledge about LTCM. highlyeducated mothers would improve the ability of mothers in seeking information and discussing, therefore, it would lead to the intention in using LTCM (Gebremariam et al, 2014).

A study by Tibaijuka et al, (2017) showed that the LTCM was mostly used by mothers with high educational level.

\section{The effect of age on the use of LTCM}

The result of this study showed that age had a relationship with long-term contraception use through education. Mothers aged $\geq 35$ years lowered the chances of using long-term contraception.

The long-term contraceptive method is more effective in maintaining the birth spacing and can be used by all ages (Winner et al., 2012). Older mothers (aged >35 years old) would be better to use a long-term contraceptive method to stop having children (Caplescu, 2014).

In this study we found out that mothers $<35$ years of age tend to prefer using longterm contraceptives, this may be caused by younger mothers will gain access to more information about the contraceptive method. Younger mothers would prefer using longterm contraception because it is considered more practical than Non-long term contraceptive method. This study is consistent with Yalew et al. (2015), which stated that the highest percentage of long-term contraceptive use were mothers aged 25 to 29 years.

\section{REFERENCE}

Alemayehu M, Kalayu A, Desta A, Gebremichael H, Hagos T, Yebyo H, (2015). Rural women are more likely to use long acting contraceptive in Tigray region, Northern Ethiopia: A comparative community-based cross sectional study. BMC Women's Health. 15(1): 1-8. doi: 10.1186/s12905-0150229-7.

Anguzu R, Tweheyo R, Sekandi JN, Zalwango V, Muhmuza C, Tusiime S, Serwadda D (2014). Knowledge and attitudes towards use of long acting reversible contraceptives among women of reproductive age in Lubaga division.BMC Research Notes.pp. 19.doi:10.1186/1756-0500-7-153

BKKBN (2016). Laporan Kinerja Instansi pemerintah 2015. p. 95.

Bulto GA, Zewdie TA, Beyen TK, (2014). Demand for long acting and permanent contraceptive methods and associated factors among married women of reproductive age group in Debre Markos Town, North West Ethiopia. BMC Women's Health. 14(1). doi: 10.1186/1472-6874-14-46.

Caplescu R, (2014). Using the Theory of Planned Behaviour to Study Fertility Intentions in Romania. Procedia Economics and Finance. Elsevier B.V., 10(14): 125-133. doi: 10.1016/S22125671(14)00285-8.

Credé S, Hoke T, Constant D, Green MS, Moodley J., Harries J (2012). Factors impacting knowledge and use of long acting and permanent contraceptive methods by postpartum HIV positive 
Journal of Health Promotion and Behavior (2018), 3(1): 37-47

https://doi.org/10.26911/thejhpb.2018.03.01.04

and negative women in Cape Town, South Africa: A cross-sectional study. BMC Public Health. BioMed Central Ltd, 12(1): 197. doi: 10.1186/14712458-12-197.

Dinas Kesehatan Provinsi Jawa Tengah (2014). Profil Kesehatan Provinsi Jawa Tengah Tahun 2014. Dinas Kesehatan Provinsi Jawa Tengah, 3511351(24): 2008-2010.

Dinas Pengendalian Penduduk dan Keluarga Berencana (2017). Catatan keadaan keluarga, PUS, alat kontrasepsi dan pelaksana KB pada PLKB Kecamatan Jebres Kota Surakarta. Surakarta.

Garret CC, Keogh LA, Kavanagh A, Tomnay J, Hocking JS, (2015). Understanding the Low Uptake of Long-Acting Reversible Contraception by Young Women in Australia: A Qualitative Study. BMC Womenn's Health. 15(1): 1-10. DOI 10.1186/s12905-015-0227-9.

Gebremariam A, Addissie A. (2014). Intention to use long acting and permanent contraceptive methods and factors affecting it among married women in Adigrat town, Tigray, Northern Ethiopia. Reproductive Health. 11(1): 24. doi: http://dx.doi.org/10.1186/17424755-11-24.

Getinet S, Abdrahman MA, Kemaw N, Kansa T, Getachew Z, Hailu DWY (2014). Long Acting Contraceptive Method Utilization and Associated Factors among Reproductive Age Women in Arba Minch Town, Ethiopia. Greener Journal of Epidemiology and Public Health, 2(1): 023-031.

Haile $\mathrm{K}$, Gebremedhin $\mathrm{M}$, Berhane $\mathrm{H}$, Gebremedhin T, Abraha A, Berhe N, Haile T, Gigar G, Girma Y (2016). Desire for birth spacing or limiting and non-use of long acting and permanent contraceptive methods among married women of reproductive age in Aksum Town, North Ethiopia. Contraception and Reproductive Medicine. Contraception and Reproductive Medicine, 1(1): 22. doi: 10.1186/s40834-016-0033-2.

Hosseini H, Torabi F, Bagi B (2014), Demand for long-acting and permanent contraceptive methods among kurdish women in Mahabad, Iran. Journal of Biosocial Science, 46(6): 772-785. doi: 10.1017/Soo21932013000710.

Kemenkes RI (2015). Kesehatan dalam Kerangka Sustainable Development Goals (SDGs).Rakorpop Kementerian Kesehatan RI, (97). 24. Available at: http://www.pusat2.litbang.depkes.go. id/pusat2_v1/wp-content/uploads/2015/12/SDGs-Ditjen-BGKIA.pdf.

(2015). Profil Kesehatan Indonesia 2014, Kementerian Kesehatan Republik Indonesia.

Mekonnen FA, Mekonnen WN, Beshah SH (2017). Predictors of long acting and permanent contraceptive methods utilization among Women in Rural North Shoa, Ethiopia. Contraception and Reproductive Medicine. 1-6. doi: 10.1186/s40834-017-0049-2.

Meskele M, Mekonnen W (2014). Factors affecting women's intention to use long acting and permanent contraceptive methods in Wolaita Zone, Southern Ethiopia: A cross-sectional study, BMC Women's Health, 14(1): 1-9. doi: 10.1186/1472-6874-14-109.

Joeliatin, Murti B, Suryani N (2016). Theory of Planned Behavior on the Determinants of Participation in the Long-Term Contraceptive Method Among Women of Reproductive Age , in Nganjuk, East Java, 1: 176-183.

Sahilemichael A (2015). Determinants of Long Acting Reversible Contracep- 
tives Use among Child Bearing Age Women in Dendi District, Western Ethiopia. Journal of Womens Health Care, 4(4). doi: 10.4172/2167-0420.1000242.

Shoupe D (2016). LARC methods: entering a new age of contraception and reproductive health.Contraception and Reproductive Medicine. 1(1): 4. doi: 10.1186/s40834-016-0011-8.

Takele A, Degu G, Yitayal M (2012). Demand for long acting and permanent methods of contraceptives and factors for non-use among married women of Goba Town, Bale Zone, South East Ethiopia. Reproductive Health, 9(1): 1-11. doi: 10.1186/17424755-9-26.

Tibaijuka L, Odongo R, Welikhe E, Mukisa W, Kugonza L, Busingye I, Nabukalu $\mathrm{P}$, Ngonzi J, Asiimwe SB, Bajunirwe F (2017). Factors influencing use of long-acting versus short-acting contraceptive methods among reproductive-age women in a resource-limited setting. BMC Women's Health. 17(1): 1-13. doi: 10.1186/s12905-017-03822.

Winner B, Peipert JF, Zhao Q, Buckel C, Medden T, Allsworth JE, Secura GM (2012). Effectiveness of Long-acting Reversible Contraception. The New England Journal of Medicine, 19982007.

Zenebe CB, Adefris M, Yenit MK, Gelaw YA (2017). Factors associated with utilization of long-acting and permanent contraceptive methods among women who have decided not to have more children in Gondar city. BMC Women's Health. 17(1): 1-7. doi: 10.1186/s12905-017-0432-9.

Yalew SA, Zeleke BM, Teferra AS (2015). Demand for long acting contraceptive methods and associated factors among family planning service users, Northwest Ethiopia: a health facility based cross sectional study. BMC Research Notes.DOI 10.1186/s13104015-0974-6. 